\title{
A comparative analysis of reverse logistics implementation for waste management in Poland and other European Union countries
}

\author{
Anetta Zielińska \\ Wroclaw University of Economics and Business \\ Wroctaw, Poland \\ anetta.zielinska@ue.wroc.pl
}

\begin{abstract}
Reverse logistics represents a current research area, in both theoretical and empirical terms. In Polish practice, reverse logistics refers to a narrow approach within the framework of waste management. Enterprises perceive their success and the source of long-term economic and social benefits in introducing new, pro-ecological solutions at various stages of the supply chain through implementing reverse logistics. The purpose of the article is to present the potential of implementing reverse logistics in view of the growing threats resulting from waste. A multidimensional comparative analysis is used in the study, based on the indicators describing waste management as an important element of reverse logistics for the European Union Member States (the EUROSTAT data). As a result, the EU countries are divided into those placed at the forefront and the ones which cannot handle the level of reverse logistics implementation through waste management. Stemming from the conducted analysis, attention was drawn to the unfavourable position of Poland in the implementation of waste management, which is manifested in the level of reverse logistics implementation.
\end{abstract}

Keywords: solid waste, waste management, recycling, reverse logistics, depletion of resources, multivariate comparative analysis, Poland, EU.

JEL Classification: Q53, Q55, Q56, Q32, C38

\section{INTRODUCTION}

Reverse logistics is an up-to-date area of scientific studies regarding both theoretical and empirical approach. In Polish practice, reverse logistics represents a narrow research field related to waste management. Enterprises aim at business success through achieving long-term economic and social benefits by implementing innovative, pro-ecological solutions at different stages of the supply chain, and one of them is reverse logistics. In recent years reverse logistics has been the area of interest for enterprises due to the savings it offers in waste management, but also from the perspective of corporate social responsibility 
and legislation. The new eco-consumer expects from modern businesses to plan pro-ecological production, to launch only pro-ecological (recycling) packaging on the market, to increase the use of recovered raw materials and relevant components in an enterprise.

Sustainability is not just another buzzword. Consumers genuinely care, and are expecting more from businesses than ever before (Sustainable Packaging Unwrapped, 2019, p. 18). This concept of sustainable development is associated with the activities and practices of businesses to achieve environmental sustainability (Naz et al., 2020, p. 2). Over one third of consumers are more willing to purchase products representing the environmentally friendly brands (Gawinowski, 2020).

Reverse logistics has become an important area for all organizations due to the growing environmental concerns, legislation, corporate social responsibility and sustainable competitiveness. Reverse logistics refers to the sequence of activities required to collect the product used by a consumer for the purpose of reuse, repair, re-manufacture, recycle or dispose of it. A careful review of literature shows that the research addressing the issue of reverse logistics is now at the evolving phase and the issues related to adoption, implementation, forecasting product performance, outsourcing, reverse logistics networks of secondary market perspective, and disposition decisions have not been thoroughly examined (Agrawal, et al., 2015).

In reverse logistics, products and components are to be made from as much recycled content as possible (wherever legally and technically feasible). This enables a reduced dependence on virgin (fossil) feedstocks and creates a demand-pull for the recycled plastics, sending a clear signal stimulating investments in collecting, sorting and recycling industry (New plastics economy ..., February 2020, p. 17). In practice, this can be achieved through implementing waste management from the smallest social unit, i.e. a household, up to an enterprise and then to a territorial unit.

The reverse logistics processes cover the following stages (de Brito, Dekker, 2003, p. 3-27; Wadhwa, et al., 2009, p. 462; Zielińska, et al., 2016, pp. 207-214):

- repairs and reuse - re-introducing the unchanged product to the system, while its quality cannot be lower than that of a new product;

- renovation (rejuvenation) - bringing the appropriate quality to returns by dismantling, control and exchange of faulty elements, and also by technological modernization being the replacement of old modules and components with the technologically better and more advanced ones;

- regeneration - bringing the appropriate quality required from new goods to the used ones through their total disassembly, a detailed repair process and exchange of out-dated parts;

- cannibalisation - recovering a relatively small number of parts and modules from a used product based on the repair process, renovation or regeneration;

- recycling - reprocessing the materials as part of the production process returns in order to obtain materials to be used in accordance with their original purpose or with another one.

All these processes create one joint reverse logistics system, of which waste management constitutes an important element (Fig. 1). In a reverse logistics system, the course of action is directed from a consumer to a producer.

Reuse models are the preferred 'inner loop' wherever relevant, and beneficial, since it retains the most value in the system. New (information) technologies, innovative business models, and evolving use patterns are unlocking and facilitating new reuse opportunities (New plastics economy ..., February 2020, p. 8). 


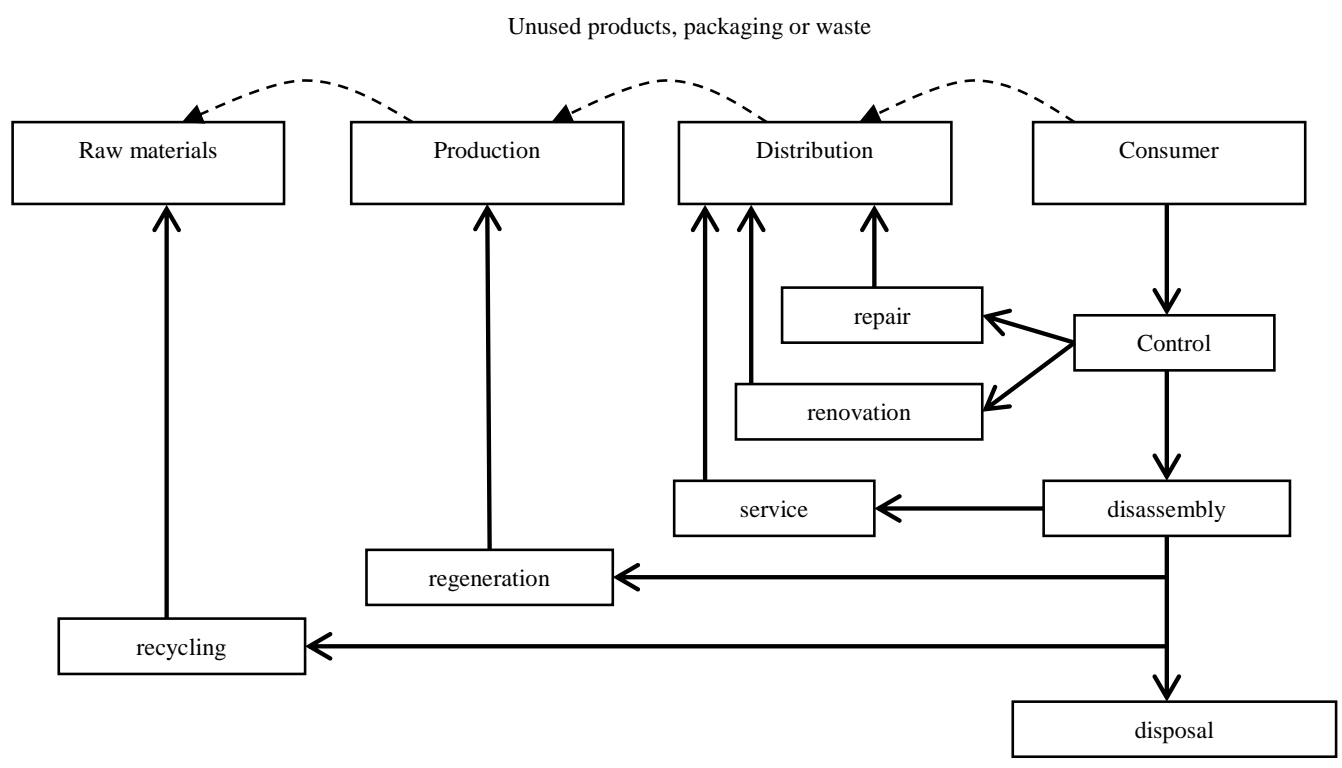

Figure 1. Reverse flow diagram

Source: Srivastava S.K. (2008)

The implementation of reverse logistics is visible already at the stage of product design by companies which apply the Design for Recycling approach, also referred to as Design for Environment, so that after using it is possible to reuse certain elements, typically considered waste, in the production of new products. This approach is followed, e.g., in the clothing industry, which establishes recycling points for clothes and underwear (clothing manufacturers: LPP - Polish, Calzedonia - Italian), the first brand second-hand shops $(\mathrm{H} \& \mathrm{M})$ or stores offering collections of clothes unsold in previous seasons (COS - online store). Price comparisons of bio-based carbon to fossil-based carbon, as well as cost comparisons of processing biobased materials with the corresponding fossil-based materials cannot be easily specified, but depend on the raw materials and the molecular economy of the processes into the final products (Popp et al., 2021, p. 77).

Over $50 \%$ of customers admitted reducing the amount of disposable plastic they use. $42 \%$ of U.S. and UK consumers say products that use sustainable materials are important when it comes to their day-to-day purchases. $73 \%$ of U.S. consumers who care about sustainable packaging say it is important to them because they are concerned about the future of the environment (Sustainable Packaging Unwrapped, March 2019, p. 8, 13 , 16). Globally, replacing just $20 \%$ of single-use plastic packaging with reusable alternatives offers an opportunity worth at least USD 10 billion (The New Plastics Economy: catalysing action, 2017). An estimated 50 million tons of electronic equipment is discarded every year globally, a figure increasing $17 \%$ a year due to the lack of reverse logistics and remanufacturing initiatives (Creating a reverse logistics ecosystem, 1.11.2020).

The purpose of the article is to present the potential for implementing reverse logistics in view of the growing threats resulting from waste. A multidimensional comparative analysis is used in the study, based on the indicators describing waste management as an important element of reverse logistics for the European Union Member States (EUROSTAT data). As a result, the EU countries are divided into those placed at the forefront and the ones which cannot handle the level of reverse logistics implementation through waste management. Based on the conducted analysis, attention was drawn to the unfavourable position of Poland in the implementation of waste management, which is manifested in the level of reverse logistics implementation. 


\section{LITERATURE REVIEW}

Scientists started defining the term reverse logistics aa early as the 1970s (Guiltinan et Nwokoye, 1975, Ginter et Starling 1978), they paid attention to returns, however, without referring to them as reverse flow logistics. It was Lambert and Stock (1981) who defined reverse logistics as the direction of flow opposite to the traditional flow of materials in the logistics chain (Lambert, et Stock, 1981). They focused on the costs of bringing the consumer's products back to the business and addressed the reverse logistics problem in terms of impact on the distribution system (Layti, et al., 2019, p. 1296). In the 1980s, Murphy (1986) defined reverse logistics as the flow of goods from the consumer to the producer in the distribution channel (Murphy, 1986, pp. 12-21). According to Pohlen and Farris (1992), reverse logistics can be defined as "the movement of consumer products towards the producer through a distribution chain" (Pohlen, et Farris II, 1992, pp. 35-47). In the 1990s, Stock (1992) formulated a definition which highlighted the role of recycling in the logistics of waste disposal and reuse (Stock, 1992, p. 7). In turn, Eymery (1997) presented a precise definition: "Reverse logistics responds to the need to withdraw the products after use and to treat them by destroying them, transforming them or recycling, in order to reduce costs by valuing recovered products and, increasingly, to meet the requirements of respect for the environment" (Eymery, 1997). According to D.S. Rogers and R.S. Tibben-Lembke (1998) reverse logistics is a process involving both planning and control of the flow of materials, work in progress, finished goods and the related information from the place of their consumption to the place of their origin, in order to recover added value or the proper method of their disposal (Rogers, et Tibben-Lembke, 1998, p. 262). M. Fleischmann et al. believe that reverse logistics is a process that covers all logistics activities, starting from the used and unnecessary products to the ones that can be reused (Fleischmann, et al., 1997, p. 5; Ślusarczyk and Kot 2018). Finally, K. Hawks claims that it is "the process of moving goods from their typical final destination for the purpose of capturing value, or proper disposal. Remanufacturing and refurbishing activities may also be included in the definition of reverse logistics" (Hawks, 2006).

In Polish literature, J. Szołtysek identifies reverse logistics with the "reverse logistics is the entirety of processes managing the flow of waste (including defected goods) and information (connected with those flows), from the places of their origin to the places of their destination in order to regain value (through repair, recycling or processing) or an appropriate treatment and long-term storage in a way that such flows were effective economically and minimized the negative influence of waste on the environment" (Szołtysek, 2009 , p. 80). A. Sadowski is of a similar opinion, as according to him reverse logistics represents the area of logistics responsible for analysing regularities occurring in the flow of products, the life cycle of which has ended (Sadowski, 2006).

The source literature suggests diverse directions of reverse logistics studies in their various aspects. Reverse logistics is analysed, e.g., from the objective and subjective, processual, decision-making, organizational and implementation oriented perspectives. All of these angles are demonstrated both theoretically and practically, and the respective studies are carried out in selected countries, sectors of industry or individual enterprises (Starostka-Patyk, 2019).

Based on the conducted source literature analysis, it is noticeable that the majority of Polish scientists approach reverse logistics as a tool for more effective waste and packaging management. The situation is different from the perspective of foreign scientists who perceive reverse logistics as a system regulating the flow of unwanted or damaged goods from a consumer to a manufacturer, i.e. managing both returns and complaints. What does it result from? It is only for several years that Poland has been implementing a functional system of waste management and obtaining the respective added value, e.g., through the process of recycling. 
Therefore, further research can illustrate the broader aspect of waste management definition as well as a more detailed approach to waste management. In accordance with the Act on Waste (Act of December 14, 2012, Art. 3, section 1, point 3), "waste management is the generation of waste and waste management", whereas (Act of December 14, 2012, Art. 3, section 1, point 2) "waste management is the collection, transport, processing of waste, including the supervision over such activities, as well as the subsequent handling of waste disposal sites and the activities performed as a waste seller or waste management intermediary".

\section{EU AND POLISH LAW REGULATING REVERSE LOGISTICS AND WASTE MANAGEMENT}

The European Union legislation regulates the guidelines for reverse logistics and waste management in the following documents:

- "Waste package" consisting of four directives: Directive 2018/851 amending Directive 2008/98/EC on waste (Directive (EU) 2018/851), Directive 2018/852 amending Directive 94/62/EC on packaging and packaging waste (Directive (EU) 2018/852), Directive 2018/850 amending Directive 1999/31/EC on the landfill of waste (Directive (EU) 2018/850), Directive 2018/849 amending Directives 2000/53/EC on end-of-life vehicles, 2006/66/EC on batteries and accumulators and waste batteries and accumulators, and 2012/19/EU on waste electrical and electronic equipment (Directive (EU) 2018/849);

- Directive 2019/904 of the impact of certain plastic products on the environment (Directive (EU) 2019/904);

- Communication, Strategy for Plastics in a Circular Economy (Communication, 16.1.2018).

Directive 2018/851, amending Directive 2008/98/EC on waste, increased the preparation levels for reuse and recycling of municipal waste (Directive 2018/851, p. 21):

a) till 2025 to a minimum of $55 \%$ by weight;

b) till $2030-60 \%$;

c) till $2035-65 \%$;

d) till 2035 the amount of municipal waste landfilled has to be reduced to $10 \%$ of the total amount of municipal waste generated.

The EU "Waste Package" is valid since 5 July 2020.

In turn, Polish legislation provides the regulations on reverse logistics and waste management in the following documents:

- The Act of September 13, 1996 on Maintaining Cleanliness and Order in Municipalities (Act, September 13, 1996),

- The Act of December 14, 2012 on Waste (Act of December 14, 2012),

- The Act of June 13, 2013 on Packaging Management and Packaging Waste (Act, June 13, 2013),

- The 2030 National Environmental Policy - development strategy in the field of environment and water management (Council of Ministers, 2019)

In order to meet the guidelines set by the European Union, Polish Parliament adopted, on November 19, 2020, the draft Act amending the Act on Maintaining Cleanliness and Order in Municipalities (Act of September 13, 1996, amendment). The adopted draft provides the levels of preparation for reuse and recycling of municipal waste which the municipalities will be obliged to achieve in the years 2021-2035. The new recycling levels for the coming years are as follows:

a) $2021-20 \%$, 
b) $2022-25 \%$,

c) $2023-35 \%$,

d) $2024-45 \%$ and

e) $2025-55 \%$.

In view of the above, Polish central government and local governments should take decisive measures aimed at reducing the total amount of generated waste. The following preventive actions are crucial: withdrawing difficult and non-recyclable products and packaging from the market, supporting reusable solutions, i.e. bottles, diapers, second-hand stores, promoting tap water drinking, preventing food waste and others (New levels of recycling ..., November 27, 2020). Waste management processes are continuously supported by legal amendments, as a result, public administration units (municipalities) and enterprises were obliged to develop efficient waste management.

\section{METHODOLOGICAL APPROACH}

The following empirical research findings were obtained based on applying a multidimensional comparative analysis (MCA) covering the European Union Member States in relation to waste management indicators, as an important element of reverse logistics for the European Union Member States on the basis of Eurostat data. The research problem is focused on the assessment of the level of waste management implementation (part of reverse logistics) in the analysed countries. The research findings aim at ordering the countries from the highest to the lowest level of waste management implementation, primarily in relation to the position of Poland.

The variety of data presented in comparative analyses in relation to waste management as an element of reverse logistics requires the use of diverse measurement units demonstrating various values. It results in the absence of possibility to compare facts and figures not only in different areas but also in the same domain, characterised by the changing intensity of specific phenomena. Taking this approach it is justified to examine the tools and methods allowing for the application of an objective procedure to assess, in general terms, the situation regarding waste management. For this reason, the method of multidimensional comparative analysis, taking the form of linear ordering, can be used in the discussed case (Zeliaś, 1989; Pluta, 1986; Pociecha, et al., 1988). Linear ordering, which uses a synthetic measure of development (SMD) provides for ranking the objects (countries) "from the best to the worst one" (Walesiak, 2006; Walesiak, et Gatnar, 2009).

The addressed research problem, i.e. the implementation level of waste management in the European Union Member States represents a complex research area. The objects of the classification (countries) are referred to by means of numerous indicators. It results in difficulties encountered when describing the similarities of objects under study as well as classifying them. The similarity level of such objects, in terms of one characteristic, may turn out different than their similarity from the perspective of another characteristic. Therefore it is crucial to classify objects based on formal procedures. It provides for an objective analysis addressing the conditions of the complexity typical for the waste management phenomenon (Zielińska, 2019, p. 341).

The first stage of multidimensional comparative analysis is focused on the unification of variables' nature (indicators referring to waste management). This unification is not applied when all variables take the form of stimulants, i.e. have a positive impact on the analysed collective problem (the condition of waste 
management). If destimulants or nominants are included in the set of indicators, they have to be converted into stimulants ${ }^{1}$.

The conversion of destimulants into stimulants through applying the quotient form (Walesiak, 1993, pp. 38-40) was used in the paper:

$$
\mathrm{S}_{i j}=\mathrm{b}\left[\mathrm{D}_{i j}\right]^{-1}
$$

where: $\mathrm{D} i j$ - value of $j$-th destimulant observed in i-th object (country),

$\mathrm{b}$ - constant adopted arbitrarily, in calculations $\mathrm{b}=\mathrm{minD}_{i j}$.

The next stage of multidimensional comparative analysis consists in removing values of the studied variables (indicators referring to waste management) and unifying orders of magnitude to make them comparable (normalization) (Walesiak, 1988, pp. 63-71). The following normalization formula was used in the discussed case (Jajuga, Walesiak, 2000, p. 109):

$$
\mathbf{z}_{\mathrm{ij}}=\frac{\mathbf{x}_{\mathrm{ij}}-\overline{\mathbf{x}}_{\mathrm{j}}}{\mathbf{S}_{\mathrm{j}}}
$$

where: $z i j$ - normalized value of $j$-th of a given waste management indicator in $i$-th object (country),

- arithmetic mean of $j$-th of waste management indicator, $j x$

$\mathrm{S} j-$ standard deviation of $j$-th waste management indicator,

$\mathrm{x} i j$ - value of $j$-th waste management indicator observed in $i$-th object (country).

The application of the normalization formula to all indicators of waste management was followed by developing a normalized data matrix (Z), applied in further calculations (see Zielińska \& Sej-Kolasa, 2004).

Having determined the normalized data matrix, the linear ordering methods were applied for the set of objects using hierarchical classification. These methods aim at ranking (ordering) the objects or their sets in accordance with the adopted criterion. It is possible to apply them only if a given overriding criterion is adopted. Next the objects can be ranked from the "best" to the "worst". The synthetic measure of development (SMD), being the tool in linear ordering methods, is the function which aggregates partial information within the individual indicators and is assigned to each single object included in the particular set. In general terms, the aggregation formulas referring to indicator values can be divided into model and non-model ones (for more see: Gatnar, et Walesiak, 2004, 351-355; Grabiński, 1984, p. 38).

A non-model formula was applied for the calculations, where $\mathrm{p} i$ takes the mean normalized value of waste management indicators for individual countries. The "best" country is considered the one with max $\mathrm{p} i$ value, whereas the "worst" - min p $i$ :

$$
\mathbf{p}_{\mathbf{i}}=\frac{1}{\mathrm{~m}} \sum_{\mathbf{j}=1}^{\mathrm{m}} \mathrm{z}_{\mathrm{ij}}
$$

where: $p i$ - synthetic measure of development for $i-$ th object (country),

$m$ - number of data describing waste management indicators,

$z i j$ - normalized value of $j$-th of a given waste management indicator in $i$-th object (country).

In the study not all waste management indicators were assigned ranks, because there is no information in the source literature or the conducted research that would describe the function of the analysed indicators in the assessment of the reverse logistics implementation.

\footnotetext{
1 The set of variables referring to waste management can cover: stimulants, destimulants and nominants. Stimulants stand for the variables the higher numerical values of which indicate the expected changes in terms of a particular phenomenon. Destimulants represent the variables the higher values of which demonstrate unwanted changes within the phenomenon under study. The features of nominants show a certain level of saturation with any deviations indicating negative changes in the examined phenomenon (Pluta, 1986).
} 


\section{CONDUCTING RESEARCH AND THE RESULTS}

A multidimensional comparative analysis was conducted applying the possible to determine waste management indicators being a part of reverse logistics for each European Union country. The indicators were retrieved from Eurostat database for 2016, 2018 and 2019. 11 waste management indicators were chosen for the analysis to describe the European Union Member States, as presented in Table 1:

1. Municipal waste generated by waste management (kilograms per capita).

2. Waste electrical and electronic equipment (WEEE) by waste management operations (kilograms per capita).

3. Recycling rates for packaging waste glass packaging (\%).

4. Recycling rates for packaging waste - plastic packaging (\%).

5. Recycling rates for packaging waste - paper and cardboard packaging (\%).

6. Recycling rates for packaging waste - wooden packaging (\%).

7. Recycling rate of e-waste (\%).

8. Disposal municipal waste - energy recovery (kilograms per capita).

9. Disposal municipal waste - landfill and other (kilograms per capita).

10. End-of-life vehicles (recovery and reuse) (\%).

11. Trade in recyclable raw materials by waste imports (thousand Euro).

Table 1

Waste management indicators in the European Union countries for 2016, 2018 and 2019

\begin{tabular}{|c|c|c|c|c|c|c|c|c|c|c|c|}
\hline Countries & \begin{tabular}{|} 
Municipal \\
waste \\
generated by \\
waste \\
management \\
(kilograms \\
per capita, \\
2018)
\end{tabular} & \begin{tabular}{|c|} 
Waste \\
electrical and \\
electronic \\
equipment \\
(WEEE) by \\
waste \\
management \\
operations \\
(kilograms \\
per capita, \\
2018)
\end{tabular} & $\begin{array}{c}\text { Recycling } \\
\text { rates for } \\
\text { packaging } \\
\text { waste } \\
\text { glass } \\
\text { packaging } \\
(\%, 2016)\end{array}$ & $\begin{array}{c}\text { Recycling } \\
\text { rates for } \\
\text { packaging } \\
\text { waste - } \\
\text { plastic } \\
\text { packaging } \\
(\%, 2016)\end{array}$ & $\begin{array}{c}\text { Recycling } \\
\text { rates for } \\
\text { packaging } \\
\text { waste - } \\
\text { paper and } \\
\text { cardboard } \\
\text { packaging } \\
(\%, 2016)\end{array}$ & $\begin{array}{c}\text { Recycling } \\
\text { rates for } \\
\text { packaging } \\
\text { waste - } \\
\text { wooden } \\
\text { packaging } \\
(\%, 2016)\end{array}$ & $\begin{array}{c}\text { Recycling } \\
\text { rate of e- } \\
\text { waste }(\%, \\
2016)\end{array}$ & $\begin{array}{c}\text { Disposal } \\
\text { municipal } \\
\text { waste - } \\
\text { energy } \\
\text { recovery } \\
\text { (kilograms } \\
\text { per capita. } \\
2018)\end{array}$ & $\begin{array}{c}\text { Disposal } \\
\text { municipal } \\
\text { waste - } \\
\text { landfill } \\
\text { and other } \\
\text { (kilograms } \\
\text { per capita, } \\
\text { 2018) }\end{array}$ & $\begin{array}{c}\text { End-of- } \\
\text { life } \\
\text { vehicles } \\
\text { (reuse, } \\
\text { recycling } \\
\text { and } \\
\text { recovery, } \\
\text { totals) } \\
(\%, 2018)\end{array}$ & \begin{tabular}{|} 
Trade in \\
recyclable \\
raw \\
materials by \\
waste \\
imports \\
(Thousand \\
euro, 2019)
\end{tabular} \\
\hline Belgium & 411 & 9,77 & 100 & 44,5 & 92,9 & 83,7 & 29,3 & 177 & 4 & 97,3 & 6273931 \\
\hline Bulgaria & 407 & 6,68 & 64 & 64,8 & 79,6 & 31,9 & 68,8 & 30 & 249 & 95,8 & 330250 \\
\hline Czechia & 351 & 9,06 & 75,1 & 58,9 & 90,6 & 51,2 & 46,5 & 58 & 172 & 99,3 & 546237 \\
\hline Denmark & 814 & 11,7 & 92,1 & 38,5 & 88,5 & 76,7 & 38,5 & 397 & 9 & 98,2 & 133370 \\
\hline \begin{tabular}{|l|} 
Germany \\
\end{tabular} & 615 & 9,13 & 84,4 & 48 & 87,6 & 25,8 & 38,7 & 192 & 5 & 95,7 & 9932823 \\
\hline Estonia & 405 & 5,57 & 61 & 26,5 & 76,9 & 16,4 & 69,8 & 167 & 87 & 91,2 & 77811 \\
\hline Ireland & 576 & 9,6 & 84,2 & 30,5 & 78,5 & 74,3 & 49,5 & 183 & 130 & 95,2 & 74055 \\
\hline Greece & 504 & 5,08 & 36 & 41,4 & 99,5 & 20,4 & 32,9 & 5 & 403 & 99,5 & 511716 \\
\hline Spain & 475 & 5,63 & 72,2 & 47,9 & 74,6 & 67,5 & 41 & 62 & 242 & 92,6 & 3035158 \\
\hline France & 527 & 10,18 & 77,9 & 26,5 & 98,4 & 30,8 & 36,6 & 185 & 110 & 94,2 & 1186974 \\
\hline Croatia & 432 & 8,21 & 57 & 37,3 & 83,7 & 2,9 & 81,3 & 0 & 286 & 97,7 & 48878 \\
\hline Italy & 499 & 4,54 & 70,8 & 42,4 & 79,7 & 60 & 34,4 & 95 & 107 & 82,6 & 4763233 \\
\hline Cyprus & 637 & 5,27 & 39,4 & 62,3 & 99,7 & 10 & 23,1 & 2 & 482 & 96,8 & 386 \\
\hline Latvia & 407 & 4,77 & 65,5 & 36,6 & 86,2 & 38 & 40,6 & 8 & 240 & 96 & 75885 \\
\hline Lithuania & 464 & 4,34 & 45,8 & 74,2 & 89,1 & 33 & 35,1 & 58 & 114 & 95,4 & 237367 \\
\hline Luxembourg & 610 & 10,17 & 98,4 & 33,4 & 83,6 & 23,6 & 45,6 & 266 & 38 & 95,9 & 809692 \\
\hline Hungary & 381 & 6,39 & 34,2 & 32 & 74,5 & 24,1 & 51,1 & 51 & 189 & 95,8 & 211946 \\
\hline Malta & 640 & 5,26 & 29,5 & 23,5 & 59,7 & 0 & 6,2 & 0 & 550 & 54,4 & 499 \\
\hline Netherlands & 511 & 8,86 & 86,2 & 50,4 & 87,1 & 72,7 & 40,4 & 218 & 7 & 98,4 & 2430995 \\
\hline Austria & 579 & 12,9 & 84,1 & 33,4 & 83,5 & 19,9 & 50,1 & 224 & 13 & 97,8 & 1535313 \\
\hline \begin{tabular}{|l} 
Poland \\
\end{tabular} & 329 & 5,98 & 63 & 34,6 & 82,2 & 32,4 & 36,1 & 79 & 137 & 95,3 & 1087760 \\
\hline Portugal & 508 & 6,17 & 49 & 34,9 & 66,9 & 89,9 & 43,5 & 91 & 247 & 94,9 & 431453 \\
\hline Romania & 272 & 2,19 & 64,1 & 46,5 & 92,5 & 27,6 & 19,4 & 12 & 200 & 92,1 & 245586 \\
\hline \begin{tabular}{|l} 
Slovenia \\
\end{tabular} & 486 & 5,87 & 98,5 & 60,4 & 76,2 & 32,2 & 33,9 & 50 & 47 & 91,3 & 493406 \\
\hline Slovakia & 414 & 5,01 & 68,7 & 52,4 & 74,2 & 47,2 & 36,7 & 34 & 229 & 96,8 & 219099 \\
\hline Finland & 551 & 9,95 & 91,8 & 26,5 & 116,1 & 14,5 & 48,2 & 314 & 4 & 97,3 & 80732 \\
\hline Sweden & 434 & 12,25 & 93 & 48,4 & 81,8 & 50,4 & 55,4 & 232 & 3 & 95,3 & 702348 \\
\hline United Kingdom & 463 & 13,04 & 67,6 & 46,2 & 79 & 30,8 & 42,2 & 181 & 69 & 92,8 & 2748987 \\
\hline
\end{tabular}

Source: own compilation on the basis of www.ec.europa.eu/ eurostat 
The presented set of indicators for the EU Member States does not provide much data to describe reverse logistics, but only the indicators describing waste management processes. It is caused by the absence of data for all countries. The majority of indicators cover 2018 (only one indicator refers to 2019). No current data are available for the indicators 3-7, therefore their levels were taken from 2016 as they were important for the analysed research problem. Table 2 presents the most important parameters for waste management indicators in the European Union Member States.

Table 2

The most important information for waste management indicators in the European Union countries for 2016, 2018 and 2019

\begin{tabular}{|c|c|c|c|c|c|}
\hline Indicators & $\begin{array}{l}\text { Arithmetic } \\
\text { mean }\end{array}$ & $\begin{array}{l}\text { Standard } \\
\text { deviation }\end{array}$ & $\begin{array}{l}\text { Nature of } \\
\text { variables: S- } \\
\text { stimulant D- } \\
\text { destimulant }\end{array}$ & $\begin{array}{l}\text { Levels max for } \\
\mathrm{S} \text { and min for } \\
\mathrm{D}\end{array}$ & $\begin{array}{l}\text { Country with } \\
\text { the the best } \\
\text { level according } \\
\text { to } \mathrm{S} \text { or } \mathrm{D} \\
\text { variable }\end{array}$ \\
\hline $\begin{array}{l}\text { Municipal waste generated by waste } \\
\text { management (kilograms per capita) }\end{array}$ & 489,4 & 113,3 & $\mathrm{D}$ & 272,0 & Romania \\
\hline $\begin{array}{l}\text { Waste electrical and electronic } \\
\text { equipment (WEEE) by waste } \\
\text { management operations (kilograms } \\
\text { per capita) }\end{array}$ & 7,6 & 2,9 & $\mathrm{D}$ & 2,2 & Romania \\
\hline $\begin{array}{l}\text { Recycling rates for packaging waste } \\
\text { glass packaging }\end{array}$ & 69,8 & 20,6 & S & 100,0 & Belgium \\
\hline $\begin{array}{l}\text { Recycling rates for packaging waste } \\
\text { - plastic packaging }\end{array}$ & 43,0 & 12,9 & S & 74,2 & Lithuania \\
\hline $\begin{array}{l}\text { Recycling rates for packaging waste } \\
\text { - paper and cardboard packaging }\end{array}$ & 84,4 & 11,2 & S & 116,1 & Finland \\
\hline $\begin{array}{l}\text { Recycling rates for packaging waste } \\
\text { - wooden packaging }\end{array}$ & 38,9 & 24,8 & $\mathrm{~S}$ & 89,9 & Portugal \\
\hline Recycling rate of e-waste & 42,0 & 15,1 & $\mathrm{~S}$ & 81,3 & Croatia \\
\hline $\begin{array}{l}\text { Disposal municipal waste - energy } \\
\text { recovery (kilograms per capita) }\end{array}$ & 120,4 & 107,3 & S & 397,0 & Denmark \\
\hline $\begin{array}{l}\text { Disposal municipal waste - landfill } \\
\text { and other (kilograms per capita) }\end{array}$ & 156,2 & 146,8 & $\mathrm{D}$ & 3,0 & Sweden \\
\hline $\begin{array}{l}\text { End-of-life vehicles (recovery and } \\
\text { reuse) }(\%)\end{array}$ & 93,8 & 8,4 & S & 99,5 & Greece \\
\hline $\begin{array}{l}\text { Trade in recyclable raw materials by } \\
\text { waste imports (Thousand euro) }\end{array}$ & 1365210,4 & 2266133,2 & S & 9932823,0 & Germany \\
\hline
\end{tabular}

Source: own compilation on the basis of www.ec.europa.eu/eurostat

The uniform preference postulate was used with reference to the analysed indicators (formula 1 was applied), where 1, 2 and 9 (indicator numbers) were classified as destimulants, following a subjective assessment, while nominants were not found in the group of the examined indicators.

The results showed in Table 2 highlight that the best levels of waste management indicators, in line with variable $\mathrm{S}$ or $\mathrm{D}$, were recorded twice in Romania. This result was influenced by the indicators 1 and 2.

At the next stage the normalization of indicators was performed (formula 2 was used), i.e. the values of indicators were deleted and the orders of magnitude were unified for comparability purposes.

The final stage consisted in a linear ordering taking the form of a synthetic measure of development (SMD) (Table 3). 
Table 3

Synthetic development measure (SDM) for the level of waste management in the European Union

countries

\begin{tabular}{|c|c|c|c|c|c|}
\hline $\begin{array}{c}\text { Country } \\
\text { position }\end{array}$ & Country name & SMD & $\begin{array}{c}\text { Country } \\
\text { position }\end{array}$ & Country name & SMD \\
\hline 1 & Belgium & 0,764 & 15 & Luxembourg & $-0,043$ \\
\hline 2 & Sweden & 0,540 & 16 & Slovakia & $-0,057$ \\
\hline 3 & Germany & 0,479 & 17 & Ireland & $-0,060$ \\
\hline 4 & Netherlands & 0,439 & 18 & Poland & $-0,068$ \\
\hline 5 & Finland & 0,405 & 19 & United Kingdom & $-0,094$ \\
\hline 6 & Romania & 0,318 & 20 & Latvia & $-0,112$ \\
\hline 7 & Denmark & 0,260 & 21 & Estonia & $-0,127$ \\
\hline 8 & Czechia & 0,256 & 22 & France & $-0,132$ \\
\hline 9 & Bulgaria & 0,128 & 23 & Croatia & $-0,170$ \\
\hline 10 & Lithuania & 0,055 & 24 & Portugal & $-0,218$ \\
\hline 11 & Spain & 0,040 & 25 & Greece & $-0,260$ \\
\hline 12 & Italy & $-0,004$ & 26 & Cyprus & $-0,328$ \\
\hline 13 & Austria & $-0,040$ & 27 & Hungary & $-0,359$ \\
\hline 14 & Slovenia & $-0,042$ & 28 & Malta & $-1,571$ \\
\hline
\end{tabular}

Source: own compilation

The highest ranked European Union Member States in terms of high level of waste management implementation, and partly also reverse logistics, are as follows: Belgium, Sweden, Germany and The Netherlands. Romania's high ranking position (No. 6) deserves attention. It may raise doubts, therefore the methodology of collecting statistical data in Romania should be carefully examined. In turn, Malta, Hungary, Cyprus and Greece are the worst implementers of waste management. Poland was ranked 18th, which is not a satisfactory result as almost $2 / 3$ of the EU countries present a higher level of waste management implementation.

Such a low position of Poland results, e.g., from the unfavourable results of two analysed indicators:

1) municipal waste disposal - energy recovery,

2) municipal waste disposal - landfills and other.

Additionally, not even one analysed indicator showed that Poland recorded the best or high result among all countries covered by the study.

In Poland, the system of municipal waste disposal through incineration with energy recovery or landfilling is poorly developed. Currently, only 9 modern municipal waste incineration plants are in operation, another one in Olsztyn is under construction. Their total capacity accounts for approx. 9.3\% of the total amount of municipal waste produced in Poland. It is definitely not enough to tie up the municipal waste management system in Poland. The optimal solution is the construction of approx. 50 installations incinerating up to 30 thousand tonnes of $\mathrm{Mg}$ combustible fraction per year, or 15, but larger ones (Wielgosiński, 2019; Szymański, 23.06.2020; Zamorowska, 30.06.2020).

Concerns are raised by the conclusions related to the level of combustible fraction from municipal waste, according to which it is not a resource in recovery processes. Feasibility studies performed 5 years ago showed that one ton of waste will result in PLN 80 profit, while at the moment it is necessary to pay additional PLN 300, i.e. the resource has turned into a cost (Marlière, 2020, p. 32).

On the other hand, the trade in recyclable raw materials by waste imports indicator is connected with the process of waste cross-border shipment. Attention should be paid to the relatively high level of this 
indicator for Poland. In recent years, Polish recovery installations have been interested in processing foreign waste suitable for recycling instead of using raw materials from the selective collection in Poland. What is the reason of such situation? - lower costs of obtaining foreign raw materials suitable for recycling.

The demand for primary (fossil) resources should be reduced by reusing the recycled materials and, at a later stage, by replacing any remaining primary raw materials with renewable ones whose source of origin is responsibly managed and remains environmentally beneficial (New Plastics Economy Global Commitment ..., October 2019, p. 41).

\section{CONCLUSIONS}

The research findings allow formulating several conclusions for Poland:

- reverse logistics represents a broader approach, not only limited to waste and packaging management, but also proper after-sales service. Businesses should invest in proper tools to handle consumer returns and complaints. As a result, it will ensure high level of customer service and a quick response of enterprises resulting in the elimination of defects in products or components;

- waste management as an element of reverse logistics should be competitive and self-financing. The process of municipal waste segregation and delivery to the recovery installations (recycling, energy recovery from combustion) should be effective both for the municipalities and the recyclers;

- ensuring readiness and ability for effective collection, segregation, processing and municipal waste reusing. It will contribute towards efficiency improvement of the system for collecting recyclable municipal waste fractions. The system should be legally and financially supported by the state and also by the external EU funds for the recovery programs;

- there are not enough modern waste recycling installations. More recycling centres should be established, specializing in the specific waste streams;

- thermal treatment of waste cannot replace recycling, but landfilling alone.

- Therefore, segregation system should be improved at its source, in particular the treatment of mixed municipal waste and its preparation for energy recovery (meeting the appropriate combustible fraction levels) or for storage.

\section{REFERENCES}

Agrawal, S., Singh, R. K., \& Murtaza, Q. (2015). A literature review and perspectives in reverse logistics. Resources, Conservation and Recycling, Vol97, 76-92.

Communication from the Commission to the European Parliament, the Council, the European Economic and Social Committee and the Committee of the Regionsa European Strategy for Plastics in a Circular Economy, Brussels, 16.1.2018 (COM(2018) 28 final).

Creating a reverse logistics ekosystem (1.11.2020). HP Brazil \& Sinctronics, from https://www.ellenmacarthurfoundation.org/case-studies/creating-a-reverse-logistics-ecosystem

de Brito M.P., Dekker R. (2003). A Framework for Reverse Logistics, W: R. Dekker, M. Fleischmann, K. Inderfurth, L. van Wassenhove (eds.), Reverse Logistics: Quantitative Models for Closed-Loop Supply Chains, Springer, Berlin, pp. 3-27.

Directive (EU) 2018/849 of the European Parliament and of the Council of 30 May 2018 amending Directives 2000/53/EC on end-of-life vehicles, 2006/66/EC on batteries and accumulators and waste batteries and accumulators, and 2012/19/EU on waste electrical and electronic equipment (Official Journal of the European Union, L 150/93, 14.6.2018).

Directive (EU) 2018/850 of the European Parliament and of the Council of 30 May 2018 amending Directive 1999/31/EC on the landfill of waste (Official Journal of the European Union, L 150/100, 14.6.2018). 
Directive (EU) 2018/851 of the European Parliament and of the Council of 30 May 2018 amending Directive 2008/98/EC on waste (Official Journal of the European Union, L 150/109, 14.6.2018).

Directive (EU) 2018/852 of the European Parliament and of the Council of 30 May 2018 amending Directive 94/62/EC on packaging and packaging waste (Official Journal of the European Union, L 150/141, 14.6.2018).

Directive (EU) 2019/904 of the European Parliament and of the Council of 5 June 2019 on the reduction of the impact of certain plastic products on the environment (Official Journal of the European Union, L 155/1, 12.6.2019).

Eymery, P. (1997). La logistique de l'entreprise - Supplychain management. Hermès éditions, Paris.

Fleischmann, M., Bloemhof-Ruwaard, J.M., Dekker, R., van der Laan, E.A., van Nunen, J.A.E.E., \& van Wassenhove L.N. (1997). Quantitative models for reverse logistics, A Review European Journal of Ope-rational Research, no. 103, $1-17$.

Gatnar, E., \& Walesiak, M. (red.), (2004). Metody statystycznej analizy wielowymiarowej w badaniach marketingowych, Wrocław: Wydawnictwo Akademii Ekonomicznej we Wrocławiu.

Gawinowski, L. (18.11.2020). Ekologia w magazynie - infografika, from https://blog.arvato.pl/ekologia-w-magazynieinfografika/

Ginter, P.M., \& Starling. (1978). Reverse distribution channels for recycling, California Management Review, Vol 20(3), $72-81$.

Grabiński, T. (1984). Wielowymiarowa analiza porównawcza w badaniach dynamiki zjawisk ekonomicznych. Kraków: Zesayty Naukowe AE w Krakowie, Seria specjalna monografie nr 61.

Guiltinan, J., \& Nwokoye, N. (1975). Reverse channels for recycling: an analysis for alternatives and public Policy implications, New marketing for social and economic Progress, Combined Proceedings. American Marketing Association.

Hawks, K. (2006). What is Reverse Logistics?, Reverse Logistics Magazine, Winter/Spring.

Jajuga, K., \& Walesiak, M. (2000). Standardisation of data set under different measurement scales, W: R. Decker, W. Gaul (Eds.), Classification and information processing AT the turn of the millennium, Springer-Verlag, Berlin, Heidelberg.

Lambert, D.M., \& Stock, J.R. (1981). Strategical Physical Distribution Management. Homewood.

Layti, MBM, Medouri, A., \& Rajaa, M. (2019). Reverse Logistics in Morocco: The Case of Hospitals, International Research Journal of Engineering and Technology, 6(10), 1296.

Marlière, H. (2020). Zamiast wielkich MBP, małe wyspecjalizowane zakłady przetwarzania. In: Ochrona środowiska w Polsce. Perspektywy najbliższych lat, Publikacja Jubileuszowa- Teraz Środowisko 2014 - 2020.

Murphy, P.R. (Summer 1986). A Preliminary Study of Transportation and Warehousing Aspects of Reverse Distribution, Transportation Journal, 25, 12-21.

Naz F., Oláh, J., Dinu, V., \& Magda, R. (2020). Green Purchase Behaviour of University Students in Hungary: An Empirical Study. Sustainability, 12(23), 10077, 1-21. DOI: 10.3390/su122310077

New Plastics Economy Global Commitment Progress Report, Ellen MacArthur Foundation, October 2019.

New plastics economy Global Commitment. Commitments, vision and definitions (February 2020). The Global Commitment.

Nowe poziomy recyklingu. Niepokój ekologów i recyklerów (27.11.2020), from https://portalkomunalny.pl/nowepoziomy-recyklingu-niepokoj-ekologow-i-recyklerow-411983/

Pluta, W. (1986). Wielowymiarowa analiza porównawcza w modelowaniu ekonometrycznym, Warszawa: Państwowe Wydawnictwo Naukowe.

Pociecha, J., Podolec, B., Sokołowski, A., \& Zając, K. (1988). Metody taksonomiczne w badaniach społecznoekonomicznych. Warszawa: PWN.

Pohlen, T.L., \& Farris II, M.T. (1992). Reverse Logistics in plastics recycling, International Journal of Physical Distribution \& Logistics Management, 22(7), 35-47.

Popp, J., Kovács, S., Oláh, J., Divéki, Z., \& Balázs, E. (2021): Bioeconomy: Biomass and biomass-based energy supply and demand. New Biotechnology, 60, 76-84, DOI: 10.1016/j.nbt.2020.10.004,

Rady Ministrów. (2019). Polityki ekologicznej państwa 2030 - strategii rozwoju w obszarze środowiska i gospodarki wodnej. Warszawa: Monitor Polski poz. 794, uchwała nr 67.

Rogers, D.S., \& Tibben-Lembke, R.S. (1998). Going backwards: Reverse Logistics Trends and Practices. University of Nevada, Center for Logistics Management, Reverse Logistics Executive Council, Pittsburgh. 
Sadowski, A. (2006). Reverselogistics w terminologii logistycznej. Logistyka, 4.

Srivastava, S.K. (2008). Network design for reverse logistics, Omega. The International Journal of Management Science, 36(4), $535-548$

Starostka-Patyk, M. (2019). Defective products management with reverse logistics processes in the furniture production companies. Polish Journal of Management Studies, 20(2), 502-515; DOI 10.17512/pjms.2019.20.2.42

Stock J.R. (1992). Reverse Logistics, Council of Logistics Management, Oak Brook.

Sustainable Packaging Unwrapped, GlobalWebIndex, March 2019.

Sustainable Packaging Unwrapped, GlobalWebIndex, March 2019.

Szołtysek, J. (2009). Logistyka zwrotna. Instytut Logistyki i Magazynowania, Poznań.

Szołtysek, J. (2009). Ewolucja logistyki zwrotnej, „Logistyka” nr 5.

Szymański, D. (23.06.2020). Spalanie odpadów. Jak i gdzie zagospodarować nadwyżkę paliwa alternatywnego?, from https://portalkomunalny.pl/jakie-spalarnie-odpadow-powinnismy-budowac-w-polsce-i-kto-powinien-bycglownym-odbiorca-rdf-u-407075/

Ślusarczyk, B., \& Kot, S. (2018). Solution for sustainable development: provisions limiting the consumption of disposable plastic carrier bags in Poland. Journal of Security and Sustainability Issues 7(3), 449-458. https://doi.org/10.9770/jssi.2018.7.3(7)

The Act of December 14, 2012 on Waste (Journal of Laws from 2020, item 797).

The Act of June 13, 2013 on Packaging Management and Packaging Waste (Journal of Laws from 2020, item 1114).

The Act of September 13, 1996 on Maintaining Cleanliness and Order in Municipalities (Journal of Laws from 2020, item 1439).

The Act of September 13, 1996 on Maintaining Cleanliness and Order in Municipalities (Journal of Laws from 2020, amendment).

The New Plastics Economy: catalysing action. (2017). Ellen MacArthur Foundation.

Wadhwa S., Madaan J., Chan F.T.S. (2009). Flexible Desicion Modeling of Reverse Logistics System: A Value Adding MCDM Aproach for Alternative Selection, Robotics and Computer-Integrated Manufacturing, 25(2), 462.

Walesiak M. (1988). Skale pomiaru cech (w ujęciu zwężonym) a zganienie wyboru postaci analitycznej syntetycznych mierników rozwoju. Wrocław: Prace Naukowe AE we Wrocławiu nr 447.

Walesiak, M., \& Gatnar, E. (2009). Statystyczna analiza danych z wykorzystaniem programu R, Warszawa: PWN.

Walesiak, M. (1993). Statystyczna analiza wielowymiarowa w badaniach marketingowych. Wrocław: Prace Naukowe AE we Wrocławiu nr 654, Seria Monografie i Opracowania nr 101.

Walesiak, M. (2006). Uogólniona miara odległości w statystycznej analizie wielowymiarowej, Wrocław: Wydawnictwo Akademii Ekonomicznej we Wrocławiu.

Wielgosiński, G. (2019). Spalarnie odpadów komunalnych w Polsce. Nowa Energia, 4.

www.ec.europa.eu/eurostat

Zamorowska, K. (30.06.2020). Liczba spalarni w Polsce. Wystarczająca czy nie?, from https://www.terazsrodowisko.pl/aktualnosci/spalarnie-lista-WPGO-gospodarka-odpadami-8903.html

Zeliaś, A. (1989). Metody taksonomii numerycznej w modelowaniu zjawisk spoteczno-gospodarczych. Warszawa: PWN.

Zielińska, A. (2019). Comparative Analysis of Circular Economy Implementation in Poland and other European Union Countries. Journal of International Studies, 12(4), 337-347. doi:10.14254/2071-8330.2019/12-4/22

Zielińska A., Prudzienica M., Mukhtar E., \& Mukhtarova K. (2016). The examples of reverse logistics application in inter-sector partnerships - good practices, Journal of International Studies, 9(3), 279-286. DOI: 10.14254/2071$8330.2016 / 9-3 / 22$ 